\title{
proposed amendment to the Constitution
}

The following amendment to the Constitution of the American Meteorological Society was approved by the Executive Committee on October 7, 1968, and by the Council on October 24, 1968. I feel particularly well qualified to write on behalf of this amendment, having been elected to the office of President-Elect in January 1968 by a plurality (not a majority) vote.

In any organization such as the American Meteorological Society, it is essential that the President have the confidence and support of the membership. The election procedure outlined in the suggested amendment, which I have personally sponsored, is one which is used by many professional and academic organizations. The procedure has "three primary advantages:

1. the President-Elect can only be named by a majority of the members voting for this office;

2. the expense and delay of a run-off election is avoided if no candidate receives a majority on the first tabulation; and

3. nominations by petition can continue to be received from the membership and are not affected by this amendment.

On behalf of the officers, Executive Committee, and Council of the American Meteorological Society, I urge the membership to endorse this constitutional change.

George S. Benton, President-Elect

Strike out Paragraph 3 of Article VI of the Constitution in its entirety, and substitute therefore the following to become effective September 1, 1969:

The ballots shall be cast by mail and to be counted must be received by the Secretary-Treasurer at the Headquarters of the Society at least thirty days prior to the date of the next Annual Meeting.

If the ballot contains either one or two candidates for the office of President-Elect, the candidate receiving the highest number of votes shall be deemed and declared to be elected to such office; and if there are three or more candidates for said office, the voter shall designate his preference by marking after the name of each candidate a number, starting with the number one, in numerical sequence. In counting the votes, the first choice of each voter shall be counted, and if the sum of said votes for any candidate represents a majority of the number of ballots cast for the office of PresidentElect, the candidate receiving said majority vote shall be deemed and declared to be elected. If no candidate has received a majority, then the candidate receiving the least number of votes shall be eliminated from further consideration and the votes of those who voted for said candidate shall be counted for the second choice of said voter. This procedure shall be repeated if necessary until one candidate has received a majority of all ballots cast, in which event he shall be deemed and declared to be elected President-Elect.

If the ballot contains more candidates for Councilor than there are available vacancies, the voter shall indicate his preference by placing a cross beside the names of a corresponding number of candidates, without designating a numerical sequence of preference. Councilors shall be elected to the available vacancies in descending order in accordance with the number of votes received.

In the event of any tie vote between two or more candidates for any office, the retiring Council shall choose between said candidates by ballot.

\section{election Pesul|is}

Announcement of the results of the election of officers and of the ballot referenda was made at the 49th annual business meeting, held at the Statler-Hilton Hotel, New York, N. Y., on 22 January 1969.

Eugene Bollay, general manager of the Environmental Science Division, EG\&G Inc., Bedford, Mass., was chosen President-Elect for 1969.

The four councilors elected by the Society's members for the three-year term, 1969-1971, are: Herbert S. Appleman, chief scientist, Physical Sciences Directorate, Headquarters, Air Weather Service, Scott AFB, Ill.; W. Boynton Beckwith, manager of meteorology, United Air Lines, Chicago, Ill.; George J. Haltiner, professor and chairman, Department of Meteorology, U. S. Naval Postgraduate School, Monterey, Calif.; and Leonard W. Snellman, chief, Scientific Services, Weather Bureau Western Region Headquarters, ESSA, Salt Lake City, Utah.

The fifth councilor, now elected by the Council for the same period, is Wayne V. Burt, professor and head, Department of Oceanography, Oregon State University, Corvallis, Oreg.

The Amendments to the Constitution and By-Laws appearing on the ballot were all approved with the required two-thirds majority vote. 